\title{
Permanent Protection: Why Canada Should Grant Permanent Residence Automatically to Recognized Refugees
}

\author{
ANDrew Brouwer
}

\begin{abstract}
In order to achieve secure status in Canada, asylum seekers must go through a lengthy, three-stage procedure involving (1) eligibility determination, (2) refugee status determination, and (3) application for permanent residence. Applicants are screened for security and criminality at both the first and third stages. During the third stage, which can take upwards of eighteen months, refugees find themselves in "legal limbo": as recognized refugees they have the right to remain in Canada, but beyond that their rights are significantly curtailed.

The author argues that the repeat screening at the permanent resident stage is unnecessary and redundant, and that the resulting delay in access to basic rights violates Canada's international obligations. The article concludes with a proposal that permanent resident status be granted automatically to refugees upon recognition as refugees.
\end{abstract}

\section{Résumé}

Pour obtenir un statut sûr au Canada, les demandeurs d'asile doivent se soumettre à un long processus de sélection, comprenant (1) la détermination d'éligibilité, (2) la détermination du statut de réfugié, et (3) la soumission d'une demande pour le statut de résident permanent. Les candidats subissent une procédure de sélection sur dossier axée sur des considérations de sécurité et de criminalité à la première étape et, de nouveau, à la troisième étape. Durant la troisième étape, qui peut prendre jusqu'à 18 mois, les réfugiés se retrouvent dans un état juridique indéterminé: en tant que réfugié reconnu, ils ont le droit de rester au Canada; mais mise à part ce fait, leurs droits sont sensiblement restreints. L'auteur soutient que l'examen au peigne fin une nouvelle fois, au stade de résident permanent, est superflu et redondant, et que le délai à l'accès aux droits fondamentaux qui en découle fait que le Canada enfreint ses obligations internationales. L'article conclut avec une recommandation que le statut de résident permanent soit automatiquement octroyé aux réfugiés dès l'instant où ils sont reconnus comme réfugiés.

\section{Introduction}

I n 2003, the Government of Canada selected 7,505 women, men, and children seeking asylum from persecution and brought them to Canada from overseas. Churches and other private groups sponsored a further 3,247 refugees, while 11,250 refugees who claimed protection after coming to Canada on their own were granted permanent residence in 2003, along with 3,958 of their dependants overseas. ${ }^{1}$

For those refugees brought to Canada by the government or sponsoring groups, arrival at the border generally marks the end of a long road. Upon arrival they are granted permanent resident status and can apply for Canadian citizenship three years later. For those who make it to Canada on their own and seek asylum at the border or within the country, however, arrival in Canada marks the beginning of a whole new ordeal.

Canada's refugee program is rooted in international law. The individual right to asylum is enshrined in the Universal Declaration of Human Rights (UDHR), which states: "Everyone has the right to seek and to enjoy in other countries asylum from persecution." ${ }^{2}$ The 1951 Convention relating to the Status of Refugees ${ }^{3}$ and its 1967 Protocol $^{4}$ give content to the right guaranteed by the UDHR, by setting out the 
obligations of states with respect to asylum seekers. States that have become parties to the Convention are bound by Article 33 not to expel or return ("refouler") a refugee "to the frontiers of territories where his life or freedom would be threatened on account of his race, religion, nationality, membership of a particular social group or political opinion." 5 The prohibition on refoulement specifically to torture is also provided for in Article 3 of the 1984 Convention against Torture and Other Cruel, Inhuman or Degrading Treatment or Punishment, ${ }^{6}$ and Article 7 of the 1966 International Covenant on Civil and Political Rights. ${ }^{7}$ So well entrenched is the principle of non-refoulement to torture that it has evolved into a customary norm of international law, ${ }^{8}$ applicable to states regardless of whether they are parties to one of the relevant conventions.

As a result of the principle of non-refoulement, states parties are obliged to consider the claims of those who request asylum in their territory or at their frontier. Canada's Immigration and Refugee Protection $A c t^{9}$ (IRPA) reflects these principles by providing for the conferral of refugee status, or "protected person" status. ${ }^{10}$ In order to receive such protection, claimants must meet a refugee definition based on the Refugee Convention, or show they face a risk of torture, a risk to life, or a risk of cruel and unusual treatment or punishment, as set out in the Convention Against Torture. They must also meet certain eligibility and admissibility criteria, as discussed below. Once they have been formally recognized as refugees and granted Canada's protection, refugees are entitled to remain in Canada. ${ }^{11}$

Recognition as a refugee or protected person, however, does not result in refugees receiving equal treatment with other residents of Canada. While protection from refoulement is generally the most immediate concern for most refugees upon arrival, other key rights protections are not available to them even after refugee protection has been granted. In order to enjoy the full range of rights enjoyed by other residents of Canada, refugees must apply for and be granted "permanent resident" status. Only after such status has been granted are refugees in a position to become full and (nearly) equal ${ }^{12}$ participants in Canadian society.

\section{Three steps to permanent status}

Refugee protection claimants seeking Canada's permanent protection must proceed via a three-step process of (1) eligibility, (2) refugee status determination, and (3) permanent residence. ${ }^{13}$

\section{Step 1: Eligibility Determination}

Under the Immigration and Refugee Protection Act (IRPA), protection claimants must pass an "eligibility" determination before their protection claim may be heard by the
Refugee Protection Division of the Immigration and Refugee Board (IRB). Eligibility determination includes both administrative matters and a criminality and security screening. Under section 100(1) of IRPA, immigration officers have three working days (seventy-two hours) from receipt of the claim to determine whether the claim is eligible to be referred to the Refugee Protection Division. If the three days pass without a determination by the immigration officer who received the claim, then the claim is "deemed to be referred."14 (It is worth noting, however, that in the event that information comes to light after referral, the immigration officer retains the power to reclassify the claim as ineligible, suspending and eventually terminating consideration of the claim by the Refugee Protection Division. ${ }^{15}$ )

Further to a January 2003 directive issued by Citizenship and Immigration Canada (CIC), officials must interview all refugee claimants arriving at the border to elicit information for admissibility, security, and criminality screening. The policy is to have "a full and complete front-end screening (examination) before the claimant is allowed into Canada." 16 Where, due to high volumes of arrivals or insufficient resources, officers find they are unable to complete the eligibility determinations within the stipulated three working days, the directive instructs them to detain ${ }^{17}$ or "direct back" claimants as measures of last resort. IRPA gives immigration officers discretion to detain a refugee claimant, without a warrant, in a variety of circumstances, including:

- in order to complete an examination, ${ }^{18}$ or

- if the officer has "reasonable grounds to believe" the person is inadmissible and poses a danger to the public, ${ }^{19}$ or

- if the officer has "reasonable grounds to suspect" the person is inadmissible on grounds of security or for violating human or international rights,,$^{20}$ or

- if the officer "is not satisfied of the identity of the foreign national..."21

Until their claim has been referred to the Refugee Protection Division, claimants have no legal status in Canada and are extremely vulnerable. Not only may they be detained without a warrant (this may also happen after referral), they are also ineligible to work, study, or receive social assistance or publicly funded medical care.

\section{Step 2: Refugee Status Determination}

Claims that are found or deemed eligible are referred to the Refugee Protection Division of the IRB, a quasi-judicial tribunal. A one-member panel ${ }^{22}$ makes a determination of the merits of the protection claim, usually following an oral hearing. ${ }^{23}$ While the lion's share of the Refugee Protection Division's work involves assessing whether a claimant 
should be granted protection, it should be noted that the Division also applies the "exclusion clauses" of the Refugee Convention. The exclusion clauses allow states to deny refugee status to claimants for whom, though they may meet the definition of a Convention refugee, there are serious grounds to believe they have committed a crime against peace, war crime, crime against humanity, serious non-political crime, or "acts contrary to the purposes and principles of the United Nations." 24 This is a second opportunity to screen out persons believed to pose a security or criminal threat to Canada or Canadians. In addition, if evidence later comes to light indicating that refugee protection was obtained fraudulently, the Minister may at any time seek to revoke ("vacate") that status..$^{25}$

The average processing time by the Refugee Protection Division is approximately twelve to sixteen months. During this period, claimants may apply for and are generally granted a temporary, renewable student authorization. ${ }^{26}$ If they are unable to otherwise support themselves, claimants may apply for, and are generally granted, a temporary, renewable employment authorization. ${ }^{27}$ There are, however, restrictions on the types of employment in which refugee claimants may engage.

While refugee claimants do not have access to provincial health insurance programs, they are covered by the Interim Federal Health (IFH) program, which covers emergency and essential health services, essential prescription medications, contraception, prenatal, and obstetrical care. ${ }^{28}$ There is no charge for the IFH coverage. Depending on their province of residence, ${ }^{29}$ refugee claimants may also be eligible for social assistance, provided they demonstrate that they have obtained or at least applied for an employment authorization and that they are looking for work. ${ }^{30}$ As well, refugee claimants seeking college or university education are generally charged tuition at foreign student rates, upwards of twice the rate charged to domestic students. ${ }^{31}$ They are usually ineligible for public or private loans and credit cards, and may face difficulty in securing rental accommodation or employment, as landlords and employers are often wary of their insecure and temporary status in Canada.

Upon being found to be a protected person by the Refugee Protection Division, a person may apply for a status document indicating her/his new status. ${ }^{32}$ Protected persons may not be removed to their country of origin except in very exceptional circumstances relating to national security or public safety. ${ }^{33}$ Protected person status is thus generally more secure than refugee claimant status. Protected persons are eligible for full provincial health insurance, usually after a three-month waiting period, during which they continue to be covered by IFH. ${ }^{34}$ They continue to be eligible for (restricted) work and study permits without cost. Post-secondary institutions in some provinces charge domestic tuition rates to protected persons, and as of $\mathrm{Au}-$ gust 2004 protected persons are also eligible for federal and in most provinces provincial student loans. ${ }^{35}$

Though better off than claimants, protected persons remain very vulnerable. While they have Canada's protection against refoulement and have access to many basic rights and privileges, their status is temporary and their rights and access to services are narrowly proscribed. As will be discussed further below, they face significant legal restrictions in employment and mobility and are unable to sponsor close family members including spouses and children.

\section{Step 3: Permanent Resident Status}

Upon recognition as refugees, protected persons are eligible to apply for permanent resident status ${ }^{36}$ (previously known as "landed immigrant" status). This policy reflects Article 34 of the Refugee Convention, which obliges states to "as far as possible facilitate the assimilation and naturalization of refugees." Permanent resident status confers many of the rights and privileges available to Canadian citizens, ${ }^{37}$ and enables holders of the status to apply for Canadian citizenship after three years. ${ }^{38}$ Protected persons seeking permanent resident status in Canada must file a written application, along with the required processing fees, within 180 days of the positive determination by the IRB. ${ }^{39}$ Applications are generally approved, provided they are not found to be inadmissible. These inadmissibility grounds are nearly identical to the grounds for ineligibility, which are considered at the front end of the process

Under the previous legislation, CIC's call centre reported that permanent residence applications took twelve to twenty-four months to process. ${ }^{40}$ The application kit explained that "these time frames include the 90-day application processing period" at CIC, but that CIC "has little control over the time it takes to complete medical, criminal and security checks." 41 This would suggest that the bulk of the waiting time (everything beyond the ninety days for processing) was caused by the background checks. Where processing extends beyond eighteen months, criminality clearances have to be renewed - a process that could in itself take a further six months. Similarly medical clearances, which lapse after twelve months, may need to be renewed, which requires re-examination by a physician. The delays caused by trying to synchronize the validity of these two certificates alone cause additional hardship and frustration to refugees.

Despite the new front-end screening procedures, little seems to have changed in the processing of permanent residence applications. Permanent residence application 
kits produced after the implementation of IRPA provide no guidance on processing times, aside from the following general acknowledgement:

The length of time it takes to receive permanent resident status varies considerably depending on individual cases. Factors such as if you have dependent children residing outside Canada or if you have lived in several countries may lengthen the process. CIC has little control over the time it takes to complete medical, criminal, and security checks. ${ }^{42}$

It seems, therefore, that the timeline continues to be determined primarily by the inadmissibility screening process - a process rendered largely redundant by the dramatic new emphasis on front-end screening. ${ }^{43}$ For applicants who have included family members abroad in their application or who lack identity documents, the time it takes to get permanent resident status can stretch on indefinitely. ${ }^{44}$ There are no enforceable public standards for processing of permanent residence applications, nor is there a formal complaint or review mechanism where timelines become unreasonable. ${ }^{45}$ During this indefinite processing and background check period, refugees remain in "legal limbo."

\section{Life in Legal Limbo}

While in general recognized refugees may expect to proceed relatively quickly to permanent resident status, the reality for many is that it takes a year or longer. The United Nations High Commission for Refugees has expressed concern that "the inability to obtain permanent residence status can be a serious impediment to integration into Canadian society." 46 Indeed, life in Canada while waiting for permanent resident status is, in many ways, life on hold.

The single most painful and damaging aspect of life in legal limbo is prolonged, agonizing, and often unforeseen family separation. It is widely recognized that due to the many barriers facing asylum seekers, refugee families are often split up, one parent attempting the perilous journey alone while the other remains behind with the children in the country of origin or the country of first asylum. ${ }^{47}$ Upon gaining asylum in Canada, then, family reunification becomes the main concern of most refugees; indeed, the newcomer community generally does not consider anyone settled in Canada until their family is here.

As will be discussed below, international human rights law protects the integrity of the family and recognizes the universal right of children to be with their parents. Nevertheless, until they are granted permanent resident status, protected persons including Convention refugees are prohibited from bringing their children and spouses to live with them in Canada. This means that, even in a straightforward case, refugees will not be reunited with their family in Canada for almost two and a half years.

In some cases, overseas dependants are not included in the original application for permanent residence. The reasons for this vary, from bad advice to an inability to locate the dependants within the 180-day period in which the permanent residence application must be filed. While keeping overseas dependants off the original application will facilitate faster processing of the refugee's permanent residence, it may have the drawback of significantly delaying acquisition of permanent resident status for the refugee's dependants. Dependants who were not included in the refugee's original application for permanent residence have one year from the day the refugee was granted permanent resident status to appear at a visa office and request permanent residence. They will be processed as part of the refugee's application. Failing that, the refugee who was granted permanent residence will have to begin the process of sponsoring their dependants under the Family Class. (In some cases, the dependant will have surpassed the age limit for sponsorship by this time, and will become ineligible to be sponsored.) As well, they will be required to pay the $\$ 975$ Right of Permanent Residence fee if they take this route (refugees are exempted from this fee for their own applications). According to CIC, Family Class sponsorships take anywhere from six months to twenty months, or longer. Thus refugee families are routinely separated for three years or more if they are not all on the same permanent residence application. Any extended family separation has consequences for emotional and financial health. Psychological problems experienced by families that have suffered severe trauma are exacerbated. ${ }^{48}$

Until recently, Convention refugees who had not yet been granted permanent resident status also faced significant barriers to travel outside Canada. They were generally not given Canadian travel documents and were thus not guaranteed re-entry to Canada if they left the country. While refugees who had "satisfactory identity documents" could seek an exception to this rule on humanitarian and compassionate grounds, undocumented refugees were denied even this possibility. ${ }^{49}$ With the implementation of the new IRPA in 2002, however, protected persons became eligible to apply for a Convention Refugee Travel Document (CRTD), after first acquiring a Protected Person Status Document. The CRTD is valid for travel to any country except the refugee's country of origin. While this should in principle eliminate concerns about refugees' ability to travel, there are reports that undocumented refugees continue to find themselves denied a CRTD, though they may under exceptional circumstances be granted a tempo- 
rary permit for emergency travel, valid for a single re-entry to Canada. ${ }^{50}$

Refugees who have not yet been granted permanent residence face several obstacles to employment. To begin with, they must apply for and regularly renew temporary work permits. Delays in processing applications at CIC often result in gaps in coverage. ${ }^{51}$ Some refugees have reported being laid off during these gaps; others have been fired when their employers discovered their authorization was not valid. Further, refugees have long reported that they face discrimination by potential employers because their Social Insurance Number, which begins with a "9", indicates their temporary status in Canada. Some find it more difficult to get employment that requires training, because employers are unwilling to invest resources training workers who they assume may only be in Canada temporarily..$^{52}$ Other refugees report that they are more vulnerable to exploitation by employers because employers know the difficulty refugees face in finding stable and adequately paid work. Without permanent resident status, protected persons are denied access to certain professions and to some types of employment that require specific insurance, including employment in the education and health care sectors. They are also ineligible for government training programs. Lack of permanent resident status also restricts access to bank loans, thereby limiting self-employment or entrepreneurship opportunities.

This exclusion and marginalization of refugees from mainstream society as a result of these restrictions has social and economic costs not just for the individuals directly affected, but also for their communities and for broader society. With respect to the social costs, it is important to recognize that refugees are by definition people who have suffered and/or have grounds to fear serious persecution. Many have been tortured or seen loved ones tortured or killed. They have come to Canada to seek refuge and to rebuild their lives. The sooner they are allowed and encouraged to do this fully, the sooner they will become fully functioning and self-supporting participants in Canadian society. On the other hand, the longer they are kept in limbo, the more entrenched they will become in marginalized communities, making it increasingly difficult to integrate into Canadian society.

\section{International Law on the Treatment of Refugees}

While there is no right to permanent resident status for refugees per se in either international refugee law or international human rights law, these areas of law do guarantee refugees a range of important civil, political, economic, social, and cultural rights. Unfortunately, in Canada the ability to enjoy these universal human rights is limited by a person's immigration status.

As the basic treaty on states' obligations vis-à-vis refugees, the 1951 Refugee Convention includes provisions on the treatment that states parties must provide to refugees in their territory. At a minimum, the Convention requires states to treat refugees as they treat aliens generally ${ }^{53}$ and to refrain from discriminating among refugees on the basis of their race, religion or country of origin. ${ }^{54}$ However, the Convention provides for higher levels of protection in several specific areas. For example, states are obliged to treat refugees at least as favourably as they do their own nationals with respect to: freedom of religion, ${ }^{55}$ access to the courts, ${ }^{56}$ access to elementary education, ${ }^{57}$ public relief, ${ }^{58}$ labour law protection, ${ }^{59}$ and social security. ${ }^{60}$ In other areas, refugees must be given "the most favourable treatment accorded to nationals of a foreign country, in the same circumstances" (e.g. non-political, non-profit freedom of association and trade unions, ${ }^{61}$ employment ${ }^{62}$ ) or treatment "as favourable as possible and, in any event, not less favourable than that accorded to aliens generally in the same circumstances" (e.g. property rights, ${ }^{63}$ housing, ${ }^{64}$ education other than elementary, recognition of foreign credentials, ${ }^{65}$ and mobility rights $\left.^{66}\right)$. In addition, the Refugee Convention obliges states to provide refugees with administrative assistance, ${ }^{67}$ identity papers, ${ }^{68}$ and travel documents. ${ }^{69}$

A number of the rights set out in the Refugee Convention are limited to refugees who are "lawfully staying" in the territory of the contracting state. ${ }^{70}$ Canadian officials have sometimes argued that this language allows Canada to deny the rights that are qualified in this way to recognized refugees who have not acquired permanent resident status. As Guy Goodwin-Gill and Judith Kumin have pointed out, however, this interpretation of the Refugee Convention is incorrect. ${ }^{71}$ Canada has a reservation to Articles 23 (public relief) and 24 (labour legislation and social security) providing that "Canada interprets the phrase 'lawfully staying' as referring only to refugees admitted for permanent residence; refugees admitted for temporary residence will be accorded the same treatment with respect to matters dealt with in Articles 23 and 24 as is accorded visitors generally."72 This reservation was made only for those two articles, however; no such reservations were made with respect to any of the other articles that use the "lawfully staying" language. In the absence of a reservation, the other articles must be read to apply not just to permanent residents but also to recognized refugees.

The rights protections articulated by the Refugee Convention have been significantly supplemented by the development of the international human rights regime in the intervening fifty years, and need to be interpreted in the 
light of these developments. ${ }^{73}$ Treaties such as the 1966 International Covenant on Civil and Political Rights ${ }^{74}$ and the 1966 International Covenant on Economic, Social and Cultural Rights ${ }^{75}$ give legal expression to the more general commitments of the 1948 Universal Declaration of Human Rights. Other treaties such as the Convention on the Elimination of All Forms of Racial Discrimination, ${ }^{76}$ the Convention on the Elimination of Discrimination Against Women, ${ }^{77}$ and the 1989 Convention on the Rights of the Child ${ }^{78}$ have combined to much more fully articulate a normative baseline of universal rights that states must respect.

The basic principle of non-discrimination lies at the heart of all of these treaties. As the UN Special Rapporteur on the Rights of Non-Citizens has observed, "The architecture of international human rights law is built on the premise that all persons, by virtue of their essential humanity, should enjoy all human rights."79 All persons, regardless of their national or ethnic origin, immigration status, or other irrelevant criteria, are equally entitled to have their human rights respected. The Covenant on Economic, Social and Cultural Rights prohibits any distinction between citizens and non-citizens with respect to economic, social, and cultural rights. ${ }^{80}$ The Covenant on Civil and Political Rights provides that, in times of domestic stability, differential treatment of non-citizens is not permissible except with respect to political participation rights and certain rights of entry and residence. ${ }^{81}$

Different treatment of non-citizens on the basis of nationality may, in some circumstances, be permissible in international law, according to the Special Rapporteur. Article 1(3) of the Convention on the Elimination of All Forms of Racial Discrimination provides: "Nothing in this Convention may be interpreted as affecting in any way the legal provisions of States Parties concerning nationality, citizenship or naturalization, provided that such provisions do not discriminate against any particular nationality." 82 Criteria for differential treatment must be assessed in light of the objects and purposes of this Convention. As the Committee on the Elimination of Racial Discrimination, the UN expert body responsible for interpreting and monitoring compliance with the Convention, has observed in its General Recommendation 14, "In seeking to determine whether an action has an effect contrary to the Convention, [the Committee] will look to see whether that action has an unjustifiable disparate impact upon a group distinguished by race, colour, descent, or national or ethnic origin." 83

However, immigration status may be used as a ground for differential treatment only in limited areas. For example, the Covenant on Civil and Political Rights may permit states to deny undocumented non-citizens freedom of movement (Art. 12), the right to choose their residence
(Art. 12), and the right to certain procedural protections in expulsion proceedings (Art. 13). These provisions should, however, be read also in the light of the Refugee Convention, which requires that states provide undocumented refugees with identity papers. The latter provision would thus remove refugees from the group against whom the state may discriminate under Articles 12 and 13 of the Covenant on Civil and Political Rights.

Articles 16(3) of the Universal Declaration of Human Rights, 23(1) of the Covenant on Civil and Political Rights, and 17(1) of the American Convention on Human Rights all provide: "The family is the natural and fundamental group unit of society and is entitled to protection by society and the State." Similar provisions may be found in the Covenant on Economic, Social and Cultural Rights, ${ }^{84}$ the African Charter on Human and Peoples Rights, ${ }^{85}$ and the European Social Charter. ${ }^{86}$ Indeed, it has been observed that there is a "universal consensus" on the right of the family to respect and protection. ${ }^{87}$ Recognition of the family as the "fundamental group unit of society" necessarily entails a right to family unity, for as Kate Jastram and Kathleen Newland observe, "if members of the family did not have the right to live together, there would not be a 'group' to respect or protect." 88

Children are granted special rights and protections under international law in view of their particular vulnerability. The Convention on the Rights of the Child requires states to make the best interests of the child a primary consideration in all actions that concern them, and to ensure protection and care for children, taking into account the rights and duties of their parents and guardians.$^{89}$ The Convention on the Rights of the Child includes specific provisions for children who have been separated from their parents or guardians..$^{90}$ It requires, inter alia, that "applications by a child or his or her parents to enter or leave a State Party for the purpose of family reunification shall be dealt with by States Parties in a positive, humane and expeditious manner." 91 Further, "A child whose parents reside in different States shall have the right to maintain on a regular basis, save in exceptional circumstances, personal relations and direct contacts with both parents." 92

The importance of family unity for refugees in particular was recognized in the Final Act of the Conference that adopted the Refugee Convention, which provides that "the unity of the family ... is an essential right of the refugee," and urges states to "take the necessary measures for the protection of the refugee's family." 93

The right of every person to leave any country is articulated in Article 13(2) of the Universal Declaration of Human Rights, as well as, inter alia, in Article 12(2) of the Covenant on Civil and Political Rights and Article 22(2) of the Ameri- 
can Declaration of Human Rights. Refugees who lack identity or travel documents, however, are often unable to exercise the right, as such documents are required both to gain entry to another country and to re-enter their country of asylum. Recognizing this pitfall, the framers of the 1951 Refugee Convention included a provision explicitly requiring that states parties provide the necessary documents to undocumented refugees in their territory. Article 28 of the Refugee Convention obliges states to "issue to refugees lawfully staying in their territory travel documents for the purpose of travel outside their territory, unless compelling reasons of national security or public order otherwise require." The article further requires that states "in particular give sympathetic consideration to the issue of such a travel document to refugees in their territory who are unable to obtain a travel document from the country of their lawful residence."

In their analysis of previous Canadian practice with respect to refugee documentation, Goodwin-Gill and Kumin note that in the absence of a reservation, Article 28 permits few exceptions to the obligation to provide travel documents to refugees. The reference to "compelling" reasons of national security and public order as justifying an exception clearly indicates that a restrictive interpretation of this exception is called for. ${ }^{94}$ The authors conclude that Canada's then failure to provide travel documents to Convention refugees who need them violated Canada's international legal obligation. Though as noted Canada has subsequently begun to issue Convention Refugee Travel Documents to refugees, the failure to do so for undocumented refugees constitutes an ongoing violation of this obligation.

The right to work is enshrined in numerous international human rights instruments, including Article 23(1) of the Universal Declaration of Human Rights, Article 6(1) of the International Covenant on Economic, Social and Cultural Rights, and Article 14 of the American Declaration of the Rights and Duties of Man. The right to work, including the right to equal access to employment and to equal treatment in the workplace, has also been elaborated in some detail through a variety of International Labour Organization instruments. The Refugee Convention itself requires that states treat refugees at least equally to foreign nationals with respect to employment, and encourages states to assimilate their rights with those of nationals. ${ }^{95}$

With respect to protected persons in Canada, however, the issue is not whether their legal right to work is formally recognized by the Canadian government - it is - but the degree to which protected persons can actually enjoy that right. The impact on employment and training opportunities of having temporary status in Canada, combined with restrictions on access to certain regulated occupations, means that refugees have less access to employment than Canadians and permanent residents. This falls afoul of Canada's international legal obligation to treat refugees without discrimination, as discussed above.

\section{Status in Canada of International Legal Protections}

Though Canada is party to all of the international human rights and refugee instruments discussed above, the federal legislature has not enacted "implementing legislation" to incorporate these instruments directly into domestic law. Government officials as well as Justice Department lawyers have traditionally argued that because the treaties have not been legally implemented, Canada is not bound to comply with them. ${ }^{96}$ However, the law of treaty interpretation, jurisprudence of the Supreme Court, and an important new provision in IRPA all indicate that international obligations voluntarily undertaken are far from irrelevant - rather, Canada is obliged to comply.

The 1969 Vienna Convention on the Law of Treaties sets out the basic law of treaty interpretation. A core provision of the Vienna Convention, which is also recognized as a pre-existing peremptory norm of international law, is the principle of good faith performance, known as pacta sunt servanda. Article 26 of the Vienna Convention states: "Every treaty in force is binding upon the parties to it and must be performed by them in good faith." 97 Thus when Canada became a party to the Refugee Convention, the two Covenants and other human rights instruments, it took on international legal obligations to perform its obligations in good faith. That Canada must, according to international law, do what it promised to do, cannot be in doubt.

Domestic jurisprudence, on the one hand, has traditionally drawn a sharp line between international law and domestic law. Only treaties that had been explicitly and directly incorporated into Canadian law were considered by the courts to have binding authority. ${ }^{98}$ On the other hand, however, the court has long recognized the rule that statutes should be interpreted as far as possible in conformity with international law, ${ }^{99}$ and it is now accepted that the Canadian Charter of Rights and Freedoms is to be interpreted in accordance with similar international human rights norms. ${ }^{100}$ In fact, recent case law goes further. In Pushpanathan v. Canada (MCI), ${ }^{101}$ Bastarache J writing for the majority applied the Vienna Convention to assess Canada's obligations under the Refugee Convention, noting that the Court had used the Vienna Convention for this purpose in two previous cases. ${ }^{102}$ In Baker v. Canada (MCI), ${ }^{103}$ the Supreme Court ruled that immigration officers were obliged to consider the Convention on the Rights of the Child - an unimplemented international treaty to which Canada 
is a party - in decisions affecting children. The majority cites the principle that "the legislature is presumed to respect the values and principles enshrined in international law, both customary and conventional."104 This approach has been affirmed in numerous subsequent decisions.

Finally, and perhaps most importantly, there is a crucial new provision in IRPA that did not exist in the previous Immigration Act. Expanding on the legislative objective to "fulfill Canada's international legal obligations with respect to refugees," 105 section 3(3)(f) provides: "This Act is to be construed and applied in a manner that ... complies with international human rights instruments to which Canada is signatory." This provision unambiguously imports Canada's international human rights obligations directly to the IRPA. By adding this provision to the new Act the legislature signaled to the Court that it intends to be legally bound by international human rights law in the field of immigration and refugee law - in any matter governed by IRPA. The earlier hesitation of the Court to bind the legislature to international treaties negotiated and ratified only by the executive should be firmly dispelled by the adoption of this provision by the legislature itself. Indeed, the Federal Court appears to have recognized this fundamental change in a number of recent decisions. ${ }^{106}$

This has significant implications for refugees in legal limbo. While Canada is under no legal obligation, domestic or international, specifically to provide permanent resident status to recognized refugees, it nevertheless is under an international obligation to treat them without distinction based on immigration status. As laid out above, international human rights law is very specific about the rights that must be accorded to all persons without distinction. Current distinctions between refugee status and permanent resident status violate these international obligations, which, under section 3(3)(f) of IRPA, are now also domestic legal obligations.

\section{Faulty Rationales}

Considering the many difficulties faced by refugees awaiting permanent residence and the fact that, as noted above, the vast majority of refugees become permanent residents eventually, one must question the policy of maintaining three distinct stages. Canada has an established and clearly articulated policy of granting permanent residence to Convention refugees. CIC itself describes the application for permanent residence as "the next step"107 for protected persons, and the IRPA requires that such applications be approved, so long as the applicant has not violated the regulations in applying and is not inadmissible. ${ }^{108}$ Section 21(2) of IRPA provides that a protected person becomes a permanent resident: if the officer is satisfied that they have made their application in accordance with the regulations and that they are not inadmissible on any ground referred to in section 34 [security] or 35 [violating human or international rights], subsection 36(1) [serious criminality] or section 37 [organized criminality] or 38 [danger to public health or safety]. ${ }^{109}$

CIC has in the past acknowledged the importance for refugees of acquiring permanent resident status as quickly as possible:

Convention refugees who do not become permanent residents in Canada remain without legal status... They enjoy only limited protection: they have a right not to be returned to the country where they fear persecution, but they do not have a right to return to Canada once they leave.... Refugees who are not permanent residents may legally take employment only if they are in possession of an employment authorization.... It is important that they initiate the landing process as early as possible...in order to entitle them to privileges and services that are acquired with full legal status. ${ }^{110}$

The existence of separate steps for protected person status followed by permanent resident status does not appear to reflect an intention to maintain two separate populations in Canada. Rather, refugee or protected person status is a way-station on the road to permanent residence. It is a way-station built under the previous legislation, prior to the shift to front-end screening, and provided the government with a first opportunity to assess the admissibility (particularly with respect to security and criminality) of persons en route from refugee claimant to permanent resident status. This way-station is now unnecessary and redundant. The screening conducted at the front end is more than adequate to screen out those who may be inadmissible for permanent residence. Requiring protected persons to undergo a second screening before granting them permanent residence is both cruel to the individuals affected and wasteful of limited public resources.

The rationales that have traditionally been put forward to justify the current approach do nothing to diminish this conclusion. The two most compelling rationales will be briefly discussed below.

The first and perhaps most obvious justification is that asylum and permanent residence are inherently quite distinct. Asylum is an internationally recognized human right rooted in international law. As a party to the Refugee Convention as well as numerous international human rights treaties, Canada must grant protection to refugees, and must treat them in accordance with the Convention and international human rights standards for as long as they 
remain on Canadian territory or are otherwise under the jurisdiction of Canadian authorities. However, Canada has no similar legal obligation to provide permanent-resident status. In contrast to the human right to asylum, permanent-resident status is considered by the Canadian government to be a "privilege" which Canada may or may not confer, according to its own policy interests. ${ }^{111}$

This distinction - between protection and permanent stay - is a matter of lively debate at the international level. It is argued by some that the conflation of refugee status and permanent residence is one of the reasons for the erosion in public support for asylum, and is damaging the always fragile political will of many, perhaps most, states to participate in refugee protection at all. ${ }^{112}$ Whatever may be the merits of maintaining the distinction in other jurisdictions, however, it makes little sense in Canada.

Perhaps the most glaring legal problem with the proposed distinction between refugee protection as international law and permanent residence as sovereign Canadian domestic policy is that, as discussed, Canada does not recognize some of the rights guaranteed to refugees by the Refugee Convention and international human rights law until they have attained permanent residence. ${ }^{113}$ As long as Canada continues to withhold from protected persons rights and benefits promised under the Refugee Convention and other international treaties, and to confer them only upon acquisition of permanent resident status, it cannot argue that permanent residence is purely a privilege that Canada is not obliged to grant to refugees under international law. While permanent residence may not be explicitly required under the Refugee Convention (though it is strongly encouraged by Article 34), some of the benefits that are only available upon becoming a permanent resident are guaranteed to refugees under such international instruments as the Refugee Convention, the Convention on the Rights of the Child, the International Covenant on Economic Social and Cultural Rights, and the Universal Declaration of Human Rights.

Canada is thus obliged either to grant permanent residence to protected persons, or to reform the existing regime to ensure that those with protected person status enjoy all of the rights and benefits to which they are entitled under international law. While the latter option would allow the government to maintain the two separate statuses, there are a number of fairly significant practical drawbacks. One is that such an approach would require amendments to a wide range of federal laws and policies that restrict certain benefits to permanent residents and citizens. It would also require negotiations with other levels of government and institutions that currently provide services, to ensure that they begin to provide their services also to protected persons. ${ }^{114}$
The other major argument for maintaining two separate steps relates to questions of security and serious criminality. The increased focus on terrorism in recent years has heightened concerns that terrorists might abuse the refugee determination system in order to remain in Canada to plan and raise funds for attacks against the U.S or even against Canadian targets. This fear underlies many reforms in the Immigration and Refugee Protection Act and associated regulations. The same concerns have led to changes in procedure introduced independently of the new legislation. Perhaps most important has been the shift in the timing of the screening procedure. Questions of security and serious criminality that were previously left for investigation at the permanent residence stage are now being addressed at the front end of the refugee determination process as well, during the eligibility stage. While such early screening makes good policy sense, the result of the introduction of front-end screening is that individuals are screened twice for almost identical factors.

The ineligibility and inadmissibility criteria related to criminality and security are identical in nearly every respect. To the extent that they are identical there is no need, from a security perspective, to maintain separate stages for protection and for permanent residence at least in principle. The vast majority of asylum seekers are neither ineligible nor inadmissible; those who are will be screened out at the front end. A second screening at the permanent residence stage is redundant.

\section{Conclusion}

The foregoing analysis indicates that the current three-stage refugee procedure of eligibility, refugee determination, and permanent residence is neither necessary nor just, and is counterproductive. It is unnecessary from a security perspective, and is unjust in that it delays full realization of certain basic rights that are guaranteed to refugees and their families. It is counterproductive because it delays integration for refugees, sometimes resulting in long-term costs to both the affected individuals and families and to the community at large. It is also unnecessary in view of the variety of remedial measures available to the Minister should there be cause to revoke permanent residency after it has been conferred. Indeed, if at any time an immigration officer reaches the opinion that a permanent resident is inadmissible, the Minister may refer the case to an inadmissibility hearing following which the individual may be removed from Canada. ${ }^{115}$

The solution to the vexing problem of refugee limbo is therefore to amend Canadian immigration policy, whether through the Act itself or via the regulations, to dispense with the second screening and to automatically grant permanent 
residence to protected persons. ${ }^{116}$ Such a move would bring Canadian policy closer to the international human rights standards it is obliged to respect, allowing refugees to enjoy without unjustifiable delay the full range of rights to which they are entitled under international law.

\section{Notes}

1. Citizenship and Immigration Canada, The Monitor, Spring 2004, Table 1, online: <http://www.cic.gc.ca/english/monitor/ issue05/02-immigrants .html $>$.

2. Universal Declaration of Human Rights, GA Res. 217 A (III), UN Doc. A/810 (1948), online: <http://www.unhchr.ch/udhr/ lang/eng.htm $>$. It is also included in Article 28 of the American Declaration of the Rights and Duties of Man, 1948, online: $<$ http://www.cidh.oas.org/Basicos/basic2.htm>.

3. Convention relating to the Status of Refugees, 28 July 1951, 189 U.N.T.S. 150, Can. T.S. 1969/6 (entered into force 22 April 1954, accession by Canada 2 September 1969) [Refugee Convention].

4. Protocol relating to the Status of Refugees, 16 December 1966, 606 U.N.T.S. 267, Can. T.S. 1969/29 (entered into force 4 October 1967, accession by Canada 4 June 1969), online: $<$ http://www.unhchr.ch/html/menu3/b/o_p_ref.htm>.

5. The non-refoulement provision is subject to exceptions. Article $1(\mathrm{C}-\mathrm{F})$ sets out circumstances under which a refugee may be excluded from protection, including for having committed war crimes, crimes against humanity, serious non-political crimes, etc.

6. Convention Against Torture and Other Cruel, Inhuman or Degrading Treatment or Punishment, 10 December 1984, A/RES/39/46, Can. T.S. 1987/36 (entered into force 26 June 1987, ratified by Canada 24 June 1987), online: <http://www. unhchr.ch/html/menu3/b/h_cat39.htm $>$.

7. International Covenant on Civil and Political Rights, 16 December 1966, 999 U.N.T.S. 171, Can. T.S. 1976/47 (entered into force 23 March 1976, accession by Canada 19 May 1976). [ICCPR], online: <http://www.unhchr.ch/html/menu3/b/ a_ccpr.htm>. Article 7 refers to the right to be free from torture, but this provision has been interpreted by the UN Human Rights Committee to include a guarantee against refoulement to torture or cruel, inhuman, or degrading treatment or punishment (General Comment 6 of the Human Rights Committee; UN Doc. HRI $\backslash G E N \backslash 1 \backslash$ Rev.1 at 6 (1994).

8. E. Lauterpacht and D. Bethlehem, "The Scope and Content of the Principle of Non-Refoulement" in E. Feller, V. Turk, and F. Nicholson, eds., Refugee Protection in International Law (Cambridge: Cambridge University Press, 2003) at 216.

9. Immigration and Refugee Protection Act, [IRPA] R.S.C. 2001, c. 27.

10. IRPA, s. 95. In this paper, "refugee" and "protected person" are used interchangeably.

11. Only if they cease to require protection (for example, if the conditions that caused them to flee no longer exist) or lose their status due to misrepresentation may they be returned.

12. While permanent resident status provides a wide range of rights and benefits, full legal equality requires citizenship status, which may be conferred on permanent residents after a three-year waiting period (reduced by up to a year for refugees).

13. This paper focuses on refugees who are recognized by the Immigration Refugee Board. However those who are rejected by the Refugee Protection Division or who are determined to be ineligible to make a refugee claim have a last-chance opportunity to acquire protected person status under the Pre-Removal Risk Assessment (PRRA) just prior to being removed. The grounds for protection under PRRA are the same as those considered by the Board during refugee determination, and applicants are screened for almost identical inadmissibility criteria as are refugee claimants before they can be accepted under the program. While the acceptance rate is exceedingly low (less than 5 per cent) the few who are accepted may apply for permanent residence. Because of these and other similarities, the arguments set forth in this paper in the refugee determination context apply equally to the PRRA context.

14. IRPA, s. 100(3).

15. Ibid., s. 103 \& 104.

16. CIC Refugees and Enforcement Branches, "Instructions for Front-end processing of refugee protection claims" (27 January 2003).

17. Authority to detain refugee claimants in these circumstances is provided by IRPA, s. 55(3)(a).

18. Per IRPA, s. 55(3)(a).

19. Ibid., s. 55(2)(a).

20. Ibid., s. 55(3)(b).

21. Ibid., s. 55(2)(b).

22. There are provisions for three-member panels in certain exceptional circumstances (IRPA, s. 163). This is new under IRPA; under the previous legislation, two-member panels were the rule (again with some exceptions).

23. In exceptional cases, where the claim is clearly a winning one, the claim will be conducted informally on an "expedited" basis.

24. IRPA, s. 98, referring to Articles $\mathrm{E}$ and F of the Refugee Convention.

25. Ibid., s. 109(1).

26. Immigration and Refugee Protection Regulations, 2002 [IRPR] SOR/2002-227, Part 8, Div 1, s. 215(1)(c)

27. IRPR, s. 206(a).

28. Citizenship and Immigration Canada, "Rights to Employment, Education and Health Care," online: <http://www. cic.gc.ca/english/refugees/asylum-5.html>.

29. Until April 2004, the province of Manitoba did not provide social assistance to claimants.

30. Canadian Council for Refugees (CCR), Refugee Rights Day Backgrounder, "Two steps forward, six steps back" (4 April 2003).

31. A. Brouwer, Equal Access to Student Loans for Convention Refugees (Ottawa: Caledon Institute of Social Policy, February 2000).

32. IRPA, s. 31 .

33. Ibid., s. 108, reflecting Article 1C of the Refugee Convention.

34. IRPR, supra note 26 . 
35. As of August 2004, all provinces that participate in the Canada Student Loan Program have harmonized their policies with that of the federal government and grant the provincial part of the loan to protected persons. Nunavut, the Northwest Territories, and the province of Quebec, which operate their own student assistance plans, do not give provincial assistance at this time, though Quebec has indicated that it plans to do so. See online: $<$ http://www.cpj.ca/studentloans $>$ for details.

36. Citizenship and Immigration Canada, online: $<\mathrm{http}: / / \mathrm{www}$. cic.gc.ca/english/refugees/asylum-2.html $>$ (date accessed: 12 April 2004)

37. Exceptions include voting rights, access to certain public positions, the right to hold a Canadian passport, etc.

38. Recognized refugees receive a reduction of up to one year in the citizenship waiting period, to reflect the time spent in Canada after refugee determination.

39. IRPR, s. 175. At the time of filing the application, protected persons are required to pay a non-refundable processing fee of $\$ 550$ for each adult family member (22 years of age and over) included in the application, as well as $\$ 150$ for each dependent child included in the application [IRPR s. 301(1)(b)]. Applicants may include dependants overseas in this application. Failure to submit an application within this time limit will result in the refugee forfeiting the opportunity to be landed as a protected person. (They must apply on humanitarian and compassionate grounds, and become subject to additional landing requirements, including medical admissibility and a \$975 Right of Landing Fee.) See IRPR 175(1); CIC Immigration Manual, Chapter PP 4: Processing Protected Persons' In-Canada Applications for Permanent Resident Status, s. 9.3, online: <http://www.cic.gc.ca/manuals-guides/english/pp/pp04e.pdf $>$.

40. Telephone call to Citizenship and Immigration Canada Call Centre by the author (March 2002).

41. Citizenship and Immigration Canada, "Applying for Permanent Residence From Within Canada: Convention Refugees," 11, online: <http://www.cic.gc.ca/english/pdffiles/kits/ KIT2. PDF $>$ (date accessed: 8 April 2002).

42. Citizenship and Immigration Canada, "Applying for Permanent Residence From Within Canada: Protected Persons and Convention Refugees," 11, online: <http://www.cic.gc.ca/ english/pdf/kits/guides/5205E.PDF> (date accessed 15 March 2003).

43. CIC maintains a Web page, updated weekly, which purports to give information on actual processing times for applications; see online: <http://www.cic.gc.ca/english/department/ times/process\%2Din.html >. On December 26, 2003, the Web site indicated a "current processing time" for applications for permanent residence by refugees and protected persons of 208 days, and reported that as of December 22, 2003, CIC was processing applications received $u p$ to June 3,2003. There is no information on the Web site about whether this figure is an average or median processing time, or a minimum. This figure is nearly double the 116-day processing time reported less than a year ago, on March 15, 2003.
44. Another group in this position are persons who are suspected of having had some association with an organization that is suspected of having had links to terrorism.

45. The only option available is to seek a writ of mandamus from the Federal Court, i.e. an order to CIC to make a decision on the case. The lack of an effective complaint mechanism is a long-standing concern of refugee policy advocates. The Canadian Council for Refugees, the Coalition for a Just Immigration and Refugee Policy, the Sanctuary Coalition, and the Maytree Foundation have all called for the establishment of an effective, independent ombudsperson's office.

46. Letter from D. McNamara, UN High Commission for Refugees, Sharry Aiken, Canadian Council for Refugees (14 May 1997).

47. K. Jastram and K. Newland, "Family Unity and Refugee Protection" in Feller, Turk, and Nicholson, supra note 8 at 559.

48. Canadian Council for Refugees (CCR), Refugee Family Reunification: Report of the Canadian Council for Refugees Task Force on Family Reunification (July 1995) at 14-20.

49. IRPR, supra note 39 at 7.

50. Conversation with Chris Pullenayagem, CPJ (25 May 2004).

51. According to CIC, the current processing period for work authorizations is fifty-three days. See online: <http://www. cic.gc.ca/english/department/times/process\%2Din.html> (date accessed: 26 December 2003).

52. H.S. Mohamed and A. Hashi, Beyond Settlement: Economic and Occupational Adjustment of the Somalis in the Ottawa-Carleton Region: Report of the Task Force on Employment Project for the Somali Community (October 1998).

53. Refugee Convention, Art. 7(1).

54. Ibid., Art. 3.

55. Ibid., Art. 4

56. Ibid., Art. 16.

57. Ibid., Art. 22(1).

58. Ibid., Art. 23.

59. Ibid., Art. 24(1)(a).

60. Ibid., Art. 24(1)(b).

61. Ibid., Art. 15.

62. Ibid., Art. 17.

63. Ibid., Art. 13.

64. Ibid., Art. 21.

65. Ibid., Art. 22(2).

66. Ibid., Art. 26.

67. Ibid., Art. 25.

68. Ibid., Art. 27.

69. Ibid., Art. 28.

70. These include the right of association (Art. 15), wage-earning employment (Art. 17), self employment (Art. 18), access to liberal professions (Art. 19), housing (Art. 21), public relief (Art. 23), labour legislation and social security (Art. 24), freedom of movement (Art. 26), travel documents (Art. 28), and expulsion (Art. 32).

71. G. Goodwin-Gill and J. Kumin, Refugees in Limbo and Canada's International Obligations (Ottawa: Caledon Institute of Social Policy, September 2000). 
72. Refugee Convention, "Declarations other than those made under section B of article 1 and Reservations," online: $<$ http://www.unhchr.ch/html/menu3/b/treaty2ref.htm $>$.

73. Vienna Convention on the Law of Treaties, 22 May 1969, 1155 U.N.T.S. 331, Can. T.S. 1980/37 (entered into force 27 January 1980, accession by Canada 14 October 1970) [Vienna Convention] Art. 31(3). See also Jastram and Newland, supra note 47 at 569 .

74. ICCPR, supra note 7.

75. International Covenant on Economic, Social and Cultural Rights, 3 January 1966, 993 U.N.T.S. 3, Can. T.S. 1976/46 (entered into force 3 January 1976, accession by Canada 19 May 1976) [ICESCR].

76. Convention on the Elimination of All Forms of Racial Discrimination, 21 December 1965, 660 U.N.T.S. 195, Can. T.S. 1970/28 (entered into force 4 January 1969, accession by Canada 14 October 1970).

77. Convention on the Elimination of Discrimination Against Women, 18 December 1979, 1239 U.N.T.S. 13, Can. T.S. 1982/31 (entered into force 3 September 1981, accession by Canada 10 December 1981) [CEDAW].

78. Convention on the Rights of the Child, 20 November 1989, Can. T.S. 1992/3 (entered into force 2 September 1990, accession by Canada 13 December 1991) [Children's Convention], online: $<\mathrm{http} / / /$ www.unhchr.ch/html/menu3/b/k2crc.htm $>$.

79. D. Weissbrodt, Prevention of Discrimination: The rights of noncitizens. Final report of the special Rapporteur, UN Doc. E/CN.4/Sub.2/2003/23 (2 May 2003) at 6.

80. ICESCR, supra 75, Art. 2(2). Note the exception for states in transition, which does not include Canada, Art. 2(3).

81. Weissbrodt, supra note 79 at 50.

82. CERD, supra note 76, Art. 1(3).

83. United Nations Committee on the Elimination of Racial Discrimination, "General Recommendation No. 14: Definition of discrimination" (22 March 1993).

84. ICESCR, supra 75, Art. 10(1).

85. African Charter on Human and Peoples' Rights, 26 June 1981 (entered into force 21 October 1986), Art. 18(1).

86. European Social Charter, 18 October 1961 (entered into force 26 February 1965), Art. 16.

87. Jastram and Newland, supra n. 47 at 566.

88. Ibid. at 566. The authors also note: "The right to marry and found a family ... includes the right to maintain a family life together. The right to a shared family life is also drawn from the prohibition against arbitrary interference with the family ... and from the special family rights accorded to children under international law."

89. Children's Convention, Art. 3(1).

90. Ibid., Arts. 9 and 10.

91. Ibid., Art. 10(1).

92. Ibid., Art. 10(2).

93. Final Act of the United Nations Conference of Plenipotentiaries on the Status of Refugees and Stateless Persons, 1951, UN Doc. A/CONF.2/108/Rev.1 (26 November 1952) Recommendation $\mathrm{B}$.

94. Goodwin-Gill and Kumin, supra note 71 at 6.
95. Refugee Convention, Art. 17. In addition, UNHCR's Executive Committee has issued Conclusions elaborating state obligations with respect to the employment of refugees.

96. See for example, Ahani v. Canada (2002), 58 O.R. (3d) 107 (C.A.). In his dissent Rosenberg J.A. summarizes the government's position with respect to its obligations as a party to the Optional Protocol to the ICCPR.

97. Vienna Convention, supra note 73, Art. 26.

98. The most cited case for this principle is the 1956 Supreme Court case of Francis v. The Queen [1956] S.C.R 618.

99. P.W. Hogg, Constitutional Law of Canada, 1999 student ed. (Toronto: Carswell, 1999) at 33.8(c), citing Re Powers to Levy Rates on Foreign Legations [1943] S.C.R. 208.

100. Slaight Communications Inc. v. Davidson [1989] 1 S.C.R 1038. 101. [1998] 1 S.C.R 982.

102. The cases are Thomson $v$. Thomson, [1994] 3 S.C.R 551, and Canada $(A G) v$. Ward, [1993] 2 S.C.R 689. For a discussion on this point see G. Van Ert, Using International Law in Canadian Courts (London: Kluwer, 2002) at 229b-c.

103. [1999] 2 S.C.R 817.

104. Ibid., quoting R. Sullivan, Dreidger on the Construction of Statutes, 3rd ed. 1994) at 330.

105. IRPA, s. 3(2)(b).

106. See, for example, Martinez v. M.C.I., [2003] F.C.J. No. 1695; Charkaoui (Re), [2003] F.C.J. No. 1816; Rimoldi v. M.C.I., [2003] F.C.J. No. 1877; Li v. M.C.I., [2003] F.C.J. No. 1934; and. Dennis v. M.C.I., [2004] F.C.J. No. 223.

107. Citizenship and Immigration Canada, online: $<$ http://www.cic.gc.ca/english/refugees/asylum-2.html> (date accessed 12 April 2004).

108. The House of Commons Standing Committee on Citizenship and Immigration, in their report on the draft Immigration and Refugee Protection Regulations, called for a regulatory provision going even further: "Those granted refugee or protected person status by the IRB should be granted permanent resident status within 60 days of the receipt of their application for permanent residence, with the IRB's determination of identity considered valid for this purpose." [House of Commons Standing Committee on Citizenship and Immigration. Report on Proposed Immigration and Refugee Protection Regulations (20 March 20 2002) Recommendation 41.]

109. The specific grounds for inadmissibility will be discussed below.

110. Citizenship and Immigration Canada, Operations Memorandum: Refugees - Time to apply for landing - Regulation 40, IL 95-02, October 16, 1995.

111. Meeting with Gerry Van Kessel, Director General, Refugees, Citizenship and Immigration Canada (February 2001).

112. See, for example, J.C. Hathaway, "Toward the Reformulation of International Refugee Law” (1996) 15:1 Refuge 1-5.

113. A further legal problem with maintaining the distinction is that permanent residence is a prerequisite in Canada for naturalization, or citizenship, and Article 34 of the Refugee Convention obliges states to "facilitate" naturalization. While 
this certainly does not in itself amount to a right to either naturalization or permanent residence, it does suggest that permanent residence is more than simply a privilege to be granted or withheld at the whim of host states. Under the Convention, refugees can legitimately expect Canadian policies to "facilitate" their obtaining Canadian citizenship, which necessarily includes granting them the prerequisite of permanent resident status.

114. A good example is the complicated nature of the harmonization of federal and provincial regulations and policies with respect to student loans for refugees. In spite of the announcement in the federal budget of February 2003 that protected persons were eligible to receive student loans, only in May 2004 did the province of Ontario adopt a policy that reflects this change in the province.

115. IRPA, s. 44-46.

116. The author and Citizens for Public Justice have put forward a number of concrete proposals in this regard. For details contact Citizens for Public Justice at cpj@cpj.ca.
Andrew Brouwer practices law with Jackman and Associates in Toronto, and is a member of the Executive Committee of the Canadian Council for Refugees. He has written numerous articles and papers on the issue of refugees in limbo in Canada. The author gratefully acknowledges the assistance of Chris Pullenayegem and Caitlin Hayward, who provided valuable research and advice, and adapted a longer version of this paper for publication. Thanks also to Janet Dench, Ninette Kelley, Harry Kits, Judith Kumin, John Frecker and Geri Sadoway for their comments and suggestions on various drafts. Notwithstanding their excellent input, the responsibility for any errors in this paper lies solely with the author. 